\title{
In-Ground Operation of Geothermic Fuel Cells for Unconventional Oil and Gas Recovery
}

\author{
Neal Sullivan ${ }^{\mathrm{a}, *}$, Gladys Anyenya ${ }^{\mathrm{a}}$, Buddy Haun $^{\mathrm{a}}$, Mark Daubenspeck ${ }^{\mathrm{a}}$, Joseph Bonadies ${ }^{\mathrm{b}}$, \\ Rick Kerr ${ }^{\mathrm{b}}$, Bernhard Fischer ${ }^{\mathrm{b}}$, Adam Wright ${ }^{\mathrm{b}}$, Gerald Jones ${ }^{\mathrm{b}}$, Robert Li ${ }^{\mathrm{b}}$, Mark Wall ${ }^{\mathrm{c}}$, \\ Alan Forbes ${ }^{\mathrm{c}}$, Marshall Savage ${ }^{\mathrm{c}}$ \\ ${ }^{a}$ Colorado Fuel Cell Center, Department of Mechanical Engineering, Colorado School of Mines, Golden, \\ CO 80401, USA \\ ${ }^{b}$ Delphi Powertrain Systems, Fenton, MI 48430, USA \\ ${ }^{c}$ IEP Technology Inc., Parker, CO 80134, USA
}

\begin{abstract}
This paper presents operating and performance characteristics of a nine-stack solid-oxide fuel cell combined-heat-and-power system. Integrated with a natural-gas fuel processor, air compressor, reactant-gas preheater, and diagnostics and control equipment, the system is designed for use in unconventional oil-and-gas processing. Termed a "Geothermic Fuel Cell" (GFC), the heat liberated by the fuel cell during electricity generation is harnessed to process oil shale into high-quality crude oil and natural gas. The $1.5-\mathrm{kW}_{e} \mathrm{SOFC}$ stacks are packaged within three-stack GFC modules. Three GFC modules are mechanically and electrically coupled to a reactant-gas preheater and installed within the earth. During operation, significant heat is conducted from the Geothermic Fuel Cell to the surrounding geology. The complete system was continuously operated on hydrogen and natural-gas fuels for $\sim$ 600 hours. A quasi-steady operating point was established to favor heat generation (29.1 $\left.\mathrm{kW}_{t h}\right)$ over electricity production $\left(4.4 \mathrm{~kW}_{e}\right)$. Thermodynamic analysis reveals a combinedheat-and-power efficiency of $55 \%$ at this condition. Heat flux to the geology averaged 3.2 $\mathrm{kW} \mathrm{m}^{-1}$ across the 9-m length of the Geothermic Fuel Cell-preheater assembly. System performance is reviewed; some suggestions for improvement are proposed.
\end{abstract}

Keywords:

SOFC application, Geothermic Fuel Cell, Oil shale, In-situ oil shale processing,

Unconventional oil and gas, SOFC-CHP

Preprint submitted to Journal of Power Sources

October 20, 2015 


\section{Introduction}

This paper presents a pilot-scale demonstration of a novel combined-heat-and-power application of solid-oxide fuel cell (SOFC) technology. The heat generated by operating SOFCs while generating electricity is harnessed to process oil shale into oil and natural gas. This "Geothermic Fuel Cell" concept is shown in Figure 1. Solid-oxide fuel cells are placed hundreds of meters below the earth's surface within the oil-shale geology and continuously operated over a period of years. The thermal energy released during fuelcell operation is harnessed to heat the surrounding oil shale to temperatures near $400{ }^{\circ} \mathrm{C}$. At these temperatures, the kerogen trapped within the oil shale is retorted to form liquid oil and natural gas. Once formed, the resources are withdrawn from the formation using conventional "collector" wells. The natural gas can be used to fuel the Geothermic Fuel Cells. Three valuable products are generated: electricity, natural gas, and most-importantly oil [1].

The demonstration presented in this paper involves a near-surface installation of nine (9) $1.5-\mathrm{kW}_{e}$ fuel cell stacks into a clay formation at the Colorado School of Mines campus. Fueled by municipal natural gas, this Geothermic Fuel Cell is integrated with a natural-gas fuel processor, a reactive-gas preheater, and ancillary balance-of-plant and diagnostic components at an outdoor test site. The Geothermic Fuel Cell was continuously operated within the earth for a period of 25 days. This paper presents the results of this demonstration.

The U.S. Geological Survey estimates that over four trillion barrels of oil are trapped in the Piceance Basin of northwestern Colorado, the Uinta Basin of northeastern Utah, and the Greater Green River Basin of southwestern Wyoming [2, 3]. In contrast to liquid shale oil (or "tight oil") trapped within porous geology [4], oil shale is a sedimentary rock that contains organic matter called kerogen [5]. When pyrolysed to $\sim 350{ }^{\circ} \mathrm{C}[6]$, this kerogen decomposes into a mixture of oil, hydrocarbon gas and carbon-rich shale coke [7]. These oilrich kerogen beds are buried below 250-600 m (800-1900 ft) of overburden, and can extend over $900 \mathrm{~m}(3,000 \mathrm{ft})$ below the surface at the center of the basins.

\footnotetext{
*Corresponding author. Tel: +1-303-273-3656.

Email address: nsulliva@mines.edu (Neal Sullivan)
} 
The processing of oil shale into oil is well established [8]. Traditionally, the shale rock is mined from the earth and then retorted above ground. Significant oil-shale retorts have been in operation for decades in Estonia, China, Russia, and other sites. Conventional oil-shale processing is not cost competitive with Middle East sources. Environmental impacts - surface disturbance, water requirements, waste management - also present significant concerns [9]. Despite the enormity of this resource, its impact on the world energy portfolio remains modest $[8]$.

Developers are turning to in-situ oil-shale processing to address these cost and environmental challenges. During in-situ processing, the oil-shale resource is retorted directly within the formation; this eliminates mining processes and minimizes surface operations [10]. Studies also show that in-situ processing leads to a significant increase in the energy yield, as greater volumes of oil shale can be processed at a time [11].

In-situ oil-shale processing is being pursued through a number of novel technologies, including:

- The "In-Situ Conversion Process" (ICP) led by Royal Dutch Shell; resistive heaters are inserted within the formation and driven with electric current to supply heat to the oil shale [7];

- The "Electrofrac Process" led by Exxon-Mobil; hydraulic fractures created in the formation are filled with an electrically conductive material to form resistive heating elements that are then driven with electric current to heat the oil shale [12];

- The "Volumetric Heating" method developed by Illinois Institute of Technology; radio waves generated by electrode arrays heat the formation [13];

- The "In-Situ Vapor Extraction Technology" pursued by Mountain West Energy; methane gas is heated above ground and injected into the oil-shale formation. A similar process is being developed by Chevron with carbon dioxide serving as the working fluid [14].

Geothermic Fuel Cells differ from these approaches in that electricity is generated throughout in-situ processing. This presents a unique Combined Heat and Power (CHP) ap- 
plication. In previous work, SOFC systems achieved CHP efficiencies approaching 85\% $[15,16,17,18,19,20]$. Unlike most CHP applications, in-situ oil-shale processing places higher value on down-hole thermal-energy release, at the expense of electricity generation. Addressing such operational tradeoffs and learning of the engineering challenges associated with underground SOFC operation motivate the current study.

\section{Experiment}

In this demonstration, a Geothermic Fuel Cell assembly was installed in the earth and continuously operated for $\sim 600$ hours. The GFC was fueled with natural gas that was passed through a fuel processor and converted into syngas. An extensive data set was acquired and used to quantify important performance metrics.

\subsection{Geothermic Fuel Cell Modules}

A schematic of a single Geothermic Fuel Cell module is shown in Figure 2. This assembly is centered on three $1.5-\mathrm{kW}_{e}$ solid-oxide fuel cell stacks that are packaged and distributed within a cylindrical stainless steel housing. The housing is approximately $0.3 \mathrm{~m}$ (1 ft.) in diameter and $1.8 \mathrm{~m}(6 \mathrm{ft}$.$) in height. Reactants are fed to the stacks in a parallel$ arrangement, while the stacks are connected in electrical series.

During operation, the fuel and air reactants fed to the stacks are electrochemically converted to products and electricity. Electrochemical oxidation occurs at $\sim 750{ }^{\circ} \mathrm{C}\left( \pm 70{ }^{\circ} \mathrm{C}\right)$ resulting in significant heat generation. This heat is liberated to the surrounding environment.

Prior to in-ground installation, Geothermic Fuel Cell prototypes were first tested in the Colorado Fuel Cell Center laboratory. These GFC modules included extensive instrumentation for monitoring GFC operation and performance. Indoor testing provided important insight to the unique operating characteristics of the GFC modules, and led to design modifications to improve performance and robustness.

For the in-ground demonstration, three GFC modules are joined using mechanical coupling. While the stacks within each module are connected in electrical series, the three 
modules are connected in electrical parallel. The assembly contains a total of nine fuel cell stacks, extends $6 \mathrm{~m}$ in length, and has an electric power rating of $13.5 \mathrm{~kW}_{e}$.

\subsection{Outdoor Test Site Description}

The in-ground Geothermic Fuel Cell architecture is shown in Figure 3. Key elements include:

1. Three mechanically and electrically coupled Geothermic Fuel Cell modules;

2. A reactive-gas preheater attached to the top of the GFCs to heat the reactant gases that feed the GFC assembly;

3. A fuel reformer that converts natural gas supplied from the local municipality into syngas;

4. Control systems and diagnostics.

The GFC modules and preheat assembly are placed within a $0.76 \mathrm{~m}$-diameter $(2.5 \mathrm{ft}$.) steel casing that separates the assembly from the surrounding geology. The casing sits within a 9.14 m-deep (30 ft) bore hole. The in-ground assembly hangs nine meters into the ground and is secured from above at the wellhead. A $1.2 \mathrm{~m}$-tall (4 ft.) wellhead module secures the entire assembly to a $0.1 \mathrm{~m}$-thick concrete pad from which the GFC-preheater assembly is suspended. The wellhead also serves as the interface for gas plumbing, the extensive diagnostic sensors, and electric power. As in the laboratory setting, the in-ground Geothermic Fuel Cell is fueled using a natural gas fuel reformer, with optional fueling using compressed hydrogen and nitrogen.

An illustration of the outdoor test site is provided in Figure 4 along with a photograph taken during GFC installation. The site consists of extensive materials and equipment for in-ground GFC operation and characterization including:

- Equipment trailer for housing of control and diagnostics hardware;

- Nearly $400 \mathrm{~m}^{3}$ (14,000 scf) of compressed hydrogen for use in startup operations;

- Liquid nitrogen dewar (1500-L) ; 
- Air compressor, backup air compressor, and air-storage tank;

- 20-kW backup electric generator;

- 480-V, 208-V, and 120-V electrical circuits.

\subsubsection{Natural Gas Fuel Reformer}

An autothermal fuel reformer supplied by Precision Combustion, Inc. (PCI, North Haven, CT, USA) is used to convert the natural gas supplied from the municipality into a hydrogen/carbon-monoxide syngas mixture. In addition to $\mathrm{H}_{2}$ and $\mathrm{CO}$, the reformate contains water vapor, carbon dioxide, nitrogen, and trace amounts of methane. The syngas generated by the reformer is used to fuel the GFCs.

Autothermal (ATR) reforming combines endothermic steam reforming (SR) and exothermic partial oxidation (POX) to create a near-thermoneutral chemical reaction. The natural gas is combined with air and water vapor oxidizers and passed over a catalyst at elevated temperature $\left(800{ }^{\circ} \mathrm{C}\right)$; the oxygen-to-carbon and steam-to-carbon ratios can be altered to vary the reformate composition $[21,22]$. Autothermal reforming reduces the need for an external heat source to drive the chemical reaction. Additionally, the reformer offers favorable start-up and response characteristics [23]. The range of operation for the PCI reformer is:

- 8-36 $\mathrm{kW}_{\text {th }}$ input energy based on the Lower Heating Value (LHV) and flow rate of natural gas;

- Variable oxygen-to-carbon $(\mathrm{O} / \mathrm{C})$ molar ratio: $0.8 \leq \mathrm{O} / \mathrm{C} \leq 1.2$ based on oxygen present in air supplied to the reformer;

- Constant steam-to-carbon $(\mathrm{S} / \mathrm{C})$ molar ratio: $\mathrm{S} / \mathrm{C}=1.0$;

- Supplemental steam addition downstream of the reactor.

The supplemental steam addition enables modification of the reformate steam-to-carbon ratio and lower heating value. Measurement of reformate composition over a range of reformer operating conditions indicates that reformer chemistry is quite close to equilibrium predictions. 


\subsubsection{Reactive Gas Preheater}

An integrated reactive-gas preheater and heat exchanger is used to heat the reactants upstream of the Geothermic Fuel Cell. An illustration of this preheater is shown in Figure 5. A counter-flow tube-in-shell architecture is utilized. This preheater/heat exchanger was designed by Saridea Inspired Engineering, LLC (Denver, CO, USA), and assembled by Deltech, Inc. (Denver, CO, USA).

Cool anode and cathode feed gases entering at the top of the preheat assembly are manifolded to a series of narrow, oval-shaped stainless-steel tubes that form an outer annulus. Heat is transferred to these cool reactants from hot exhaust gases exiting the preheat combustor and the GFC from the bottom. The natural-gas-fueled preheat combustor provides the bulk of the thermal power. A stainless steel inner shield forms the inner annulus of the preheat assembly. Fuel-cell electric power, sensor diagnostics, and combustor gas feeds are plumbed through this inner shield. The shield has fins welded to its outer diameter that extend into the exhaust channel. These fins induce mixing and promote heat transfer from the hot exhaust gases to the heat-exchanger tubing and cool reactant gases.

The burner operating conditions span:

- 8.3-16 $\mathrm{kW}_{\text {th }}$ input energy based on the LHV and flow rate of natural gas;

- Fuel flow rate $0.20-0.68 \mathrm{~g} \mathrm{~s}^{-1}$;

- Air flow rate 5.5-17.6 $\mathrm{g} \mathrm{s}^{-1}$.

The preheater assembly is packaged within a stainless-steel housing (not shown) that is coupled to the top of the GFC modules within the bore-hole. The preheater is $3 \mathrm{~m} \mathrm{(10} \mathrm{ft)}$ in length.

\subsection{Testing Description}

The Geothermic Fuel Cell system was operated during November and December of 2014. The average air temperature during the $\sim 600$ hours of operation was $1.1^{\circ} \mathrm{C}\left(34^{\circ} \mathrm{F}\right)$, with highs and lows of 17.8 and $-7.2{ }^{\circ} \mathrm{C}\left(64\right.$ and $\left.19{ }^{\circ} \mathrm{C}\right)$, respectively. 
During startup, the SOFC stacks are brought to operating temperature using electricresistance heaters contained within the Geothermic Fuel Cell modules. The electric heaters continuously provided $20 \mathrm{~kW}$ of thermal energy into the GFC during this start-up period. During heat up, a non-explosive hydrogen-nitrogen mixture $\left(5 \% \mathrm{H}_{2}\right.$ and $\left.95 \% \mathrm{~N}_{2}\right)$ was fed to the nine GFC stacks.

After reaching a minimum stack operating temperature, the fuel composition was switched from the hydrogen-nitrogen mixture to reformate. Reformer performance was confirmed through measurement of reformate composition using a gas chromatograph. The reformate composition was: $23.7 \% \mathrm{H}_{2}, 10.4 \% \mathrm{CO}, 29 \% \mathrm{H}_{2} \mathrm{O}, 2.4 \% \mathrm{CO}_{2}, 33.7 \% \mathrm{~N}_{2}$, and $0.19 \% \mathrm{CH}_{4}$. This reformate composition was continuously monitored and found to remain constant for the duration of testing.

The Geothermic Fuel Cell was continuously operated under natural gas reformate for $\sim 190$ hours. During the first 90 hours of reformate operation, the electric current drawn from the GFC was varied between 0 and 90 A. Following this series of intermittent tests, the current draw set to a constant value of $65 \mathrm{~A}$ for the remaining 100 hours of operation under reformate. While "steady-state", time-invariant conditions were never achieved, quasisteady operation was observed over 24 hours of reformate operation at the 65 -A condition. The following section summarizes in-ground GFC system performance over this 24-hour period.

\section{Results and Discussion}

\subsection{System Performance}

A number of state points were explored over the 600 hours of in-ground Geothermic Fuel Cell operation. While this represents an important demonstration for the GFC technology, this time period is relatively brief, comprising less than $2 \%$ of the four-year operating duration for which the GFC is designed.

As expected, the high temperature of the solid-oxide fuel cell stacks and low temperature of the surrounding geology led to high transfer of heat from the GFC to its surroundings. 
This places higher demands on the GFC for production of heat, rather than generation of electricity. As will be shown, the in-ground GFC was operated under conditions that maximize heat output in order to meet these thermal demands. While this led to considerable geological heating during the 600 hours of operation, the corresponding electricity generation and the resulting electrical efficiency were comparatively modest.

The in-ground GFC was operated at the 65-A condition for 100 hours. The 24 hours of quasi-steady operation at the 65-A condition provide a baseline operating point for GFC performance analysis.

Because of the series/parallel interconnection of the in-ground GFC stacks and modules, the $65 \mathrm{~A}$ of current is distributed across the three GFC modules, resulting in an average of $21.7 \mathrm{~A}$ per module, and $21.7 \mathrm{~A}$ per stack. It is important to note that the electrical architecture of the in-ground GFC is designed for higher-current operation, perhaps as high as 150 A. Therefore, far-higher electricity generation is possible with the in-ground GFC than was demonstrated during this 600-hour test.

Table 1 presents a performance summary for the in-ground Geothermic Fuel Cell at the 65-A condition. The values shown in this table are calculated using 24-hour averages of the temperatures and mass flow rates measured during operation. The sensible and chemical energies of the gas streams are calculated from the measured temperatures $(T)$ and mass flow rates $(\dot{m})$ :

$$
\begin{array}{cl}
\text { Sensible : } & \dot{Q}_{s}=\sum_{i}\left(\dot{m}_{i} c_{p, i}\right) \cdot T \\
\text { Chemical : } & \dot{Q}_{c h}=\sum_{i} \dot{m}_{i} \cdot L H V_{i}
\end{array}
$$

where $i$ denotes the individual gaseous species contained in each stream and $c_{p, i}$ is the specific heat capacity for species $i$.

The heat loss from the in-ground assembly to the surroundings $\left(\dot{Q}_{\text {heat }}\right)$ is determined by evaluating the energy balance for a control volume around the components: 


$$
\left[\dot{Q}_{s}+\dot{Q}_{c h}\right]_{\text {in }}-\left[\dot{Q}_{s}+\dot{Q}_{c h}\right]_{\text {out }}-\dot{W}_{\text {elec }}=\dot{Q}_{\text {heat }}
$$

where $\dot{W}_{\text {elec }}$ is the electric power generated by the solid-oxide fuel cell stacks.

At the $65-\mathrm{A}$ condition, the complete GFC system was fed with $60.8 \mathrm{~kW}$ of chemical power. This chemical power comes from three inputs:

1. Natural gas fed to the fuel reformer;

2. Natural gas fed to the preheater combustor;

3. Supplemental hydrogen added to the reformate stream.

The chemical power was supplemented by $10.8 \mathrm{~kW}$ of heat supplied by the GFC's internal electrical-resistance heaters. This supplemental electric heating serves to maintain the target stack temperatures $\left(680-820^{\circ} \mathrm{C}\right)$ during operation. An additional $1.7 \mathrm{~kW}$ of thermal power is used to preheat the air that feeds the autothermal reformer. The total energy input to the in-ground Geothermic Fuel Cell system is $73.3 \mathrm{~kW}$.

At the $65-\mathrm{A}$ condition, $4.4 \mathrm{~kW}$ of electric power was continuously generated by the solid-oxide fuel cell stacks. As stated previously, this power draw is less than one third of the rated capacity of the GFC stacks. Operating conditions yielding higher electric power will be explored as our experience with GFC system operation grows. This results in a modest electrical efficiency of $7.2 \%$. The low efficiency is primarily attributed to the low fuel utilization (25.9\%) used for this series of tests.

Thermodynamic analyses reveal that the three Geothermic Fuel Cell modules liberated $18.8 \mathrm{~kW}$ of thermal power into the surrounding geology. In addition, the preheat unit drove $10.2 \mathrm{~kW}$ into the geology, increasing the total thermal power entering the geology to 29.1 $\mathrm{kW}$. This resulted in a heat flux to the geology of $3.2 \mathrm{~kW} \mathrm{~m}^{-1}$ across the $9-\mathrm{m}$ length of GFCpreheater assembly. This is clearly well above the electric power generated by the stacks, as needed during initial startup conditions. The thermal efficiency for providing heat to the geology was $47.8 \%$; the combined heat-and-power efficiency reached $55.0 \%$.

Figure 6 depicts the relative distribution of energy across system outputs. The fraction of energy that represents the electrical power harnessed $(4.4 \mathrm{~kW})$ is small relative to the 
heat lost to the geology $(29.1 \mathrm{~kW})$. This is due to the high heating demands placed on the GFC, as opposed to electricity generation, during initial operation. It is expected that as the geology grows warmer, more energy conversion can be directed towards electricity generation rather than heat liberation.

Significant thermal energy is also lost in the hot exhaust gases exiting the GFC-preheat assembly $(8.4 \mathrm{~kW})$. Such losses are signficant in this near-surface demonstration, but will decrease as the Geothermic Fuel Cells are installed in deeper geological locations. Inefficiency in the autothermal reformer is also considerable $(9.2 \mathrm{~kW})$.

The energy lost due to unreacted reformate gases exiting the GFC is most significant $(22.3 \mathrm{~kW})$. While this unused fuel negatively impacts efficiency, the ability to pass reformate through the GFC without conversion is an important design feature, as it provides a measure of turndown in device operation. This enables a decrease in thermal and/or electrical output from the GFCs as the geology grows warmer, preventing overheating.

For this demonstration, the unreacted reformate was simply flared above ground. It is reasonable to consider that the unreacted fuel could be used in a number of ways to improve system performance. Unreacted reformate gases could be routed to the preheat combustor, reducing (perhaps even eliminating) the consumption of natural gas in this combustor. Thermodynamic calculations indicate that such a change would increase the CHP efficiency from $55.0 \%$ to $66.0 \%$ for the same conditions tested.

Alternatively, the anode exhaust could be "recycled" into the reformate fuel that feeds the GFC. Anode recycle has been shown to markedly improve system performance $[24,25,26]$. This change would necessitate use of a high-temperature anode-recycle blower. Such a blower would need to withstand the high temperatures of the anode exhaust gases $(>200$ ${ }^{\circ} \mathrm{C}$ ), and require power and control hardware for proper operation [27, 28]. However, these unreacted reformate gases exit the GFC at temperatures that are lower than those found in typical SOFC systems, perhaps reducing the cost of this balance-of-plant component. 


\subsection{Component Performance}

This section presents the performance of the key components that comprise the Geothermic Fuel Cell System: the fuel reformer, the reactant preheater, and the Geothermic Fuel Cell modules.

The reformer is equipped with an air heater upstream of the reactor, and two "supplemental" steam generators that provide superheated steam to the reformate downstream of the reactor. The supplemental steam is provided in addition to the water that is injected with the air and natural gas into the catalytic reactor body. Operating conditions for the autothermal reformer were held constant throughout the 100 hours of operation at the $65-\mathrm{A}$ condition:

- $36 \mathrm{~kW}_{t h}$ chemical energy input;

- $1.0 \times 10^{-3} \mathrm{~m}^{3} \mathrm{~s}^{-1}(60 \mathrm{slpm})$ natural gas flow rate;

- $3.1 \times 10^{-3} \mathrm{~m}^{3} \mathrm{~s}^{-1}(183 \mathrm{slpm})$ air flow rate $(1.16 \mathrm{O} / \mathrm{C}$ ratio);

- $8.1 \times 10^{-1} \mathrm{~g} \mathrm{~s}^{-1}$ steam flow rate $(1.0 \mathrm{~S} / \mathrm{C}$ ratio);

- $7.1 \times 10^{-1} \mathrm{~g} \mathrm{~s}^{-1}$ supplemental steam flow rate.

As listed previously, the measured reformate composition was very close to chemicalequilibrium predictions, with very little methane slip. The reformer efficiency (Eq.4) is evaluated based on the LHVs of the natural gas supply and the hydrogen product [21]:

$$
\eta_{A T R}=\frac{\left(\dot{n}_{H_{2}}+\dot{n}_{C O}\right) \cdot L H V_{H_{2}}}{\dot{n}_{C H_{4}} \cdot L H V_{C H_{4}}}=75.1 \%
$$

This definition assumes complete shifting of the carbon monoxide into $\mathrm{CO}_{2}$ through the water-gas shift reaction, yielding one mole of $\mathrm{H}_{2}$ for every mole of $\mathrm{CO}$ in the reformate:

$$
\mathrm{CO}+\mathrm{H}_{2} \mathrm{O} \rightarrow \mathrm{H}_{2}+\mathrm{CO}_{2}
$$


Before the reformed natural gas is fed to the GFC, additional hydrogen (20 slpm) is injected to the fuel stream to increase its chemical power. This supplemental hydrogen is not included in the ATR efficiency calculation.

The flow of energy through the preheater is shown pictorially in Figure 7. The preheater is quite effective in increasing reactant-gas temperatures to SOFC-stack operating conditions. The air and reformate gases exit the preheater at 697 and $748{ }^{\circ} \mathrm{C}$, respectively. These temperatures are quite well matched, and near the stack temperatures.

When operating at the $65-\mathrm{A}$ condition, the reactant gases pick up $19.0 \mathrm{~kW}$ of thermal power when passing through the preheater. There are two sources of this thermal energy: the high-temperature gases exiting the natural gas combustor, and the hot exhaust gases exiting the GFC modules. The combustor serves the primary heating role: $16.8 \mathrm{~kW}$ of thermal power are released through combustion, while $12.6 \mathrm{~kW}$ are liberated by the hot exhaust ( $8.0 \mathrm{~kW}$ from the air, $4.6 \mathrm{~kW}$ from the anode exhaust).

Much of the heat generated by the combustor and liberated by the GFC exhaust is transferred to the cool reactants $(65 \%)$. However, heat transferred from the preheater to the surrounding geology is also substantial $(10.4 \mathrm{~kW})$.

A similar thermodynamic analysis of the three Geothermic Fuel Cell modules reveals that the GFCs drive $18.7 \mathrm{~kW}$ of thermal energy into the surrounding geology. The reactants bring nearly $52 \mathrm{~kW}$ of sensible and chemical energy into the GFC assemblies. The internal electric heaters generate $10.8 \mathrm{~kW}$ of heat within the GFC modules. The SOFCs electrochemically convert the chemical energy within the reactants into $4.4 \mathrm{~kW}$ of electricity, while $39.6 \mathrm{~kW}$ of sensible and chemical energy exit the GFCs through the exhaust. The remainder (18.7 $\mathrm{kW})$ is released to the surrounding geology.

\subsection{Geology Heating}

Temperatures in the surrounding geology were periodically measured over the course of the in-ground Geothermic Fuel Cell testing. Figure 8a depicts the geology temperature as a function of depth from the surface on two consecutive days of $65-\mathrm{A}$ operation. These measurements were taken within a bore hole located $1.2 \mathrm{~m}$ (3.9 ft.) from the GFC casing. 
A substantial temperature difference is observed with depth below the surface; the highest temperatures are observed at $3.7 \mathrm{~m}$ from the surface, nearly adjacent to the top-most stack. The lowest temperatures and highest temperature gradients are found close to the surface.

At depths greater than $4 \mathrm{~m}$, geology temperature gradually decreases with increasing depth into the earth. This reflects the higher volume of geology that must be heated at the bottom of the GFC. Heat transfer in the radial direction is dominant near the middle of the GFC-preheater assembly (depth of $4.5 \mathrm{~m}$ ); axial heat transfer is also significant at the ends of the assembly. These fairly pronounced end effects result in the lower temperatures at the extreme positions. Overall, the geology temperature is found to increase by over $3{ }^{\circ} \mathrm{C}$ in the 24-hour period between the two series of measurements.

Geology temperature as a function of radial position from the GFC casing is shown in Figure $8 \mathrm{~b}$. This logarithmic temperature profile is consistent with the general solution for one-dimensional radial heat conduction into an infinite homogeneous medium [29]. Such a result may prove valuable for future modeling of the geology-heating process.

\section{Conclusions}

This paper reports on the design and performance of the world's first Geothermic Fuel Cells. Three cylinderical GFC modules, each containing three $1.5 \mathrm{kWe}$ solid-oxide fuel cell stacks, were mechanically and electrically coupled and joined to a gas-preheater/heatexchanger assembly. The 9-m-long assembly was placed within the earth, integrated with extensive balance-of-plant components, controls, and diagnostics, then continuously operated over a period of 600 hours. An initial data set was gathered, and the effectiveness of the GFCs in heating the surrounding geology while simultaneously generating electricity was demonstrated.

In an effort to establish a steady operating point, the Geothermic Fuel Cell system was set at an electrical current output of $65 \mathrm{~A}$ while fueled with reformed natural gas. With the SOFC stacks within the GFC assembly operating at temperatures as high as $800{ }^{\circ} \mathrm{C}$, and the surrounding geology at temperatures less than $100{ }^{\circ} \mathrm{C}$, high heat transfer was observed from the GFC assembly to the surroundings. This necessitated a Geothermic Fuel Cell 
operating condition that favored generation of thermal energy over generation of electricity. Key operating characteristics under this condition include:

- $4.4 \mathrm{~kW}$ of continuous electricity generation;

- $29.2 \mathrm{~kW}$ of heat transferred from the GFC-preheater assembly to the surrounding geology, with $18.8 \mathrm{~kW}$ liberated by the GFCs, and $10.3 \mathrm{~kW}$ provided by the preheater;

- $55 \%$ combined heat-and-power efficiency;

- $3.2 \mathrm{~kW} \mathrm{~m}^{-1}$ of heat flux transferred to the geology across the $9 \mathrm{~m}$ length of the GFCpreheater assembly.

The $22.4 \mathrm{~kW}$ of energy loss from the low fuel utilization and ensuing unreacted reformate exiting the GFC is the primary source of the relatively low system electrical efficiency (7.2\%). Considerable performance increases could be realized by harnessing the chemical and thermal energy in the unreacted fuel exiting the GFC.

The use of Geothermic Fuel Cells in unconventional oil-and-gas recovery presents an exciting new application for solid-oxide fuel cell technology. For the present study, the primary resource to be accessed is the four-trillion barrels of oil trapped within U.S. oil-shale reserves. Other potential applications include down-hole steam generation for accessing tight oils and advanced conventional oil recovery.

\section{Acknowledgment}

Design and development of the solid-oxide fuel cell stacks used in the Geothermic Fuel Cell modules is based upon work supported by the Department of Energy under Award Number DE-FE00011769. The authors wish to thank Mr. Okan Saribal of Saridea and Dr. Saurab Vilekar of Precision Combustion, Inc. for fruitful discussions regarding balance-ofplant component integration and operation, and Prof. Robert Braun of the Colorado School of Mines for insightful discussions on system optimization. 


\title{
NOMENCLATURE
}

\author{
ATR autothermal reforming \\ CHP combined heat and power \\ GFC Geothermic Fuel Cell \\ HX heat exchanger \\ ICP In-situ Conversion Process \\ LHV lower heating value $\left(\mathrm{kJ} \mathrm{kmol}^{-1}\right)$ \\ NG natural gas \\ $\mathrm{O} / \mathrm{C}$ oxygen to carbon ratio \\ PCI Precision Combustion Inc. \\ POX partial oxidation \\ $\mathrm{S} / \mathrm{C} \quad$ steam to carbon ratio \\ SOFC Solid Oxide Fuel Cell \\ SR steam reforming \\ $c_{p, i} \quad$ specific heat capacity $\left(\mathrm{k} J K g^{-1} K^{-1}\right)$ \\ $\dot{m}_{i} \quad$ mass flow rate $\left(\mathrm{Kg} \mathrm{s}^{-1}\right)$ \\ $\dot{n}_{i} \quad$ molar flow rate $\left(\mathrm{kmol} \mathrm{s}^{-1}\right)$ \\ $\dot{Q}_{\mathrm{s}} \quad$ sensible energy $(\mathrm{kW})$ \\ $\dot{Q}_{\text {ch }} \quad$ chemical energy $(\mathrm{kW})$ \\ $\dot{Q}_{\text {heat }}$ heat loss to geology $(\mathrm{kW})$ \\ $T \quad$ temperature $(\mathrm{K})$ \\ $\dot{W}_{\text {elec }} \quad$ electric power $(\mathrm{kW})$ \\ $\eta_{\text {ATR }} \quad$ reformer efficiency $(\%)$
}

\section{References}

[1] M. T. Savage, Linearly Scalable Geothermic Fuel Cells, US patent US 6684948 (02 2007).

[2] R. C. Johnson, T. J. Mercier, M. E. Brownfield, J. G. Self, Assessment of in-place oil shale resources in 
the Eocene Green River Formation, Uinta Basin, Utah and Colorado, U.S. Geological Survey Digital Data Series DDS-69-BB (2010) p. 153.

[3] J. Birdwell, T. Mercier, R. Johnson, M. Brownfield, In-place oil shale resources examined by grade in the major basins of the Green River Formation, Colorado, Utah, and Wyoming, U.S. Geological Survey Fact Sheet 2012-3145.

[4] World Energy Council, World Energy Resources 2013 Survey (2013) p. 468.

[5] J. Birdwell, T. Mercier, R. Johnson, M. Brownfield, In-place oil shale resources of the Mahogany Zone, Green River Formation, sorted by grade, overburden thickness, and stripping ratio, Piceance Basin, Colorado, and Uinta Basin, Utah, U.S. Geological Survey Fact Sheet 2015-3005.

[6] Q. Li, X. Han, Q. Liu, X. Jiang, Thermal decomposition of Huadian oil shale. Part I. Critical organic intermediates, Fuel 121 (2014) 109-116.

[7] A. Brandt, Converting oil shale to liquid fuels: Energy inputs and greenhouse gas emissions of the Shell in-situ conversion process, Enviromental Science and Technology 42 (2008) 7489-7495.

[8] J. R. Dyni, Geology and resources of some world oil-shale deposits, U.S Geological Survey Scientific Investigations Report 2005-5294 (2006) p. 42.

[9] J. Bauman, C. Huang, M. Gani, M. Deo, Oil Shale: A solution to the liquid fuel dilemma, American Chemical Society, Washington DC, USA, 2010, Ch. 7, pp. 135-146.

[10] M. C. Branch, In-situ combustion retorting of oil shale, Progress in Energy and Combustion Science 5 (1979) 193-206.

[11] G. Marland, A. M. Perry, D. B. Reister, Net energy analysis of in-situ oil shale processing, Energy 3 (1978) 31-41.

[12] W. A. Symington, D. L. Olgaard, G. A. Otten, T. C. Phillips, M. M. Thomas, J. D. Yeakel, ExxonMobil's Electrofrac process for in-situ oil shale conversion, in: Proceedings of the AAPG Annual Convention, San Antonio, USA, April 20-23 2008, American Association of Petroleum Geologists, TX, USA, 2008, pp. 04-33.

[13] R. Carlson, E. Blase, T. McLendon, Development of the IIT Research Institute RF heating process for in-situ oil shale/tar sand fuel extraction - an overview, in: Proceedings of the 14th Oil Shale Symposium, Colorado School of Mines, Golden, USA, 1981, pp. 04-22.

[14] A. Bolonkin, J. Friedlander, S. Neumann, Strategic Solutions Technology Group, Innovative unconventional oil extraction technologies, Fuel Processing Technology 124 (2014) 228-242.

[15] K. Nanaeda, F. Mueller, J. Brouwer, S. Samuelsen, Dynamic modeling and evaluation of solid oxide fuel cell combined heat and power system operating strategies, Journal of Power Sources 195 (2010) 3176-3185.

[16] R. J. Kee, A. M. Colclasure, H. Zhu, FUEL CELLS - SOLID OXIDE FUEL CELLS - Cells and 
Stacks, Encyclopedia of Electrochemical Power Sources 3 (2009) 51-62.

[17] A. A. Trendewicz, R. J. Braun, Techno-economic analysis of solid oxide fuel cell-based combined heat and power systems for biogas utilization at wastewater treatment facilities, Journal of Power Sources 233 (2013) 380-393.

[18] E. Fontell, T. Kivisaari, N. Christiansen, J.-B. Hansen, J. Palsson, Conceptual study of a $250 \mathrm{~kW}$ planar SOFC system for CHP application, Journal of Power Sources 131 (2004) 49-56.

[19] P. Lisbona, A. Corradetti, R. Bove, P. Lunghi, Analysis of a solid oxide fuel cell system for combined heat and power applications under non-nominal conditions, Electrochimica Acta 53 (2007) 1920-1930.

[20] S. J. Cooper, G. P. Hammond, M. C. McManus, A. Ramallo-Gonzlez, J. G. Rogers, Effect of operating conditions on performance of domestic heating systems with heat pumps and fuel cell microcogeneration, Energy and Buildings 70 (2014) 52-60.

[21] S. H. Lee, D. Applegate, S. Ahmed, S. G. Calderone, T. L. Harvey, Hydrogen from natural gas: part I - Autothermal reforming in an integrated fuel processor, International Journal of Hydrogen Energy 30 (2005) 829-842.

[22] S. Ahmed, M. Krumpelt, Hydrogen from hydrocarbon fuels for fuel cells, International Journal of Hydrogen Energy 26 (2001) 291-301.

[23] A. Heinzel, B. Vogel, P. Hübner, Reforming of natural gas-hydrogen generation for small scale stationary fuel cell systems, Journal of Power Sources 105 (2002) 202-207.

[24] R. Dietrich, J. Oelze, A. Lindermeir, C. Spitta, M. Steffen, T. Kuster, S. Chen, C. Schlitzberger, R. Leithner, Efficiency gain of solid oxide fuel cell systems by using anode offgas recycle - Results for a small scale propane driven unit, Journal of Power Sources 196 (2011) 7152-7160.

[25] J. Jia, Q. Li, M. Luo, L. Wei, A. Abudula, Effects of gas recycle on performance of solid oxide fuel cell power systems, Energy 36 (2011) 1068-1075.

[26] S. Wahl, A. G. Segarra, P. Horstmann, M. Carre, W. G. Bessler, F. Lapicque, K. A. Friedrich, Modeling of a thermally integrated $10 \mathrm{~kW}_{e}$ planar solid oxide fuel cell system with anode offgas recycling and internal reforming by discretization in flow direction, Journal of Power Sources 279 (2015) 656-666.

[27] R. Peters, R. Deja, L. Blum, J. Pennanen, J. Kiviaho, T. Hakala, Analysis of solid oxide fuel cell system concepts with anode recycling, International Journal of Hydrogen Energy 38 (2013) 6809-6820.

[28] L. Vincenzo, N. M. Pagh, K. S. Knudsen, Ejector design and performance evaluation for recirculation of anode gas in a micro combined heat and power systems based on solid oxide fuel cell, Applied Thermal Engineering 54 (2013) 26-34.

[29] J.F. Branco, C.T. Pinho, R.A. Figueiredo, A dimensionless analysis of radial heat conduction with variable external convection boundary conditions, International Communications in Heat and Mass Transfer 28 (2001) 489-497. 


\begin{tabular}{|c|c|c|}
\hline $\begin{array}{l}\text { Total chemical } \\
\text { power into system }(\mathrm{kW})\end{array}$ & 60.8 & $\begin{array}{c}\text { (Power in NG to reformer) + (Power in NG into preheat combustor) } \\
+\left(\text { Power in supplemental } \mathrm{H}_{2} \text { to GFC) }\right.\end{array}$ \\
\hline Total heat into system $(\mathrm{kW})$ & 12.5 & (Preheating of reactants at ATR) + (GFC internal electric heaters) \\
\hline Stack electric power $(\mathrm{kW})$ & 4.4 & (Electric current) ${ }^{*}$ (GFC terminal voltage) \\
\hline System electrical efficiency (\%) & 7.2 & (Stack electric power) / (Total chemical power into system) \\
\hline Fuel utilization (\%) & 25.8 & $\begin{array}{l}\text { (Moles of } \mathrm{H}_{2} \text { consumed to produce electric current) / } \\
\text { (Moles of }\left[\mathrm{H}_{2}+\mathrm{CO}+3^{*} \mathrm{CH}_{4}\right] \text { fed to GFC) }\end{array}$ \\
\hline GFC heat loss to geology (kW) & 18.8 & $\begin{array}{l}\text { [Total chemical and sensible energy in GFC inlet gases } \\
\text { Total energy in GFC exhaust gases] - GFC electric power }\end{array}$ \\
\hline $\begin{array}{l}\text { Preheater heat loss to } \\
\text { geology }(\mathrm{kW})\end{array}$ & 10.4 & $\begin{array}{l}\text { [Total (chemical and sensible) energy in the preheater inlet } \\
\text { gas streams] - [Total energy in preheater outlet gas streams] }\end{array}$ \\
\hline Total heat loss to geology (kW) & 29.1 & (Heat loss from GFC) + (Heat loss from pre-heat unit) \\
\hline System heating efficiency (\%) & 47.8 & $\begin{array}{l}\text { (Total heat loss to surroundings) / } \\
\text { (Total chemical power into system) }\end{array}$ \\
\hline $\begin{array}{c}\text { Combined heat and power } \\
\text { efficiency }(\%)\end{array}$ & 55.0 & (System electrical efficiency) + (System heating efficiency) \\
\hline $\begin{array}{l}\text { Heat loss per unit length of GFC } \\
\qquad(\mathrm{kW} / \mathrm{m})\end{array}$ & 3.2 & $\begin{array}{l}\text { (Heat loss to geology) / } \\
\text { (6 m GFC length }+3 \mathrm{~m} \text { of Pre-Heater length) }\end{array}$ \\
\hline Reformer efficiency (\%) & 75.1 & (Chemical power in reformate) /(Chemical power in NG fuel ) \\
\hline Heat exchanger efficiency (\%) & 65.1 & $\begin{array}{c}\text { (Heat gained by GFC inlet gases) / [(Heat from NG combustion) } \\
+(\text { Heat loss from GFC exhaust streams)] }\end{array}$ \\
\hline
\end{tabular}




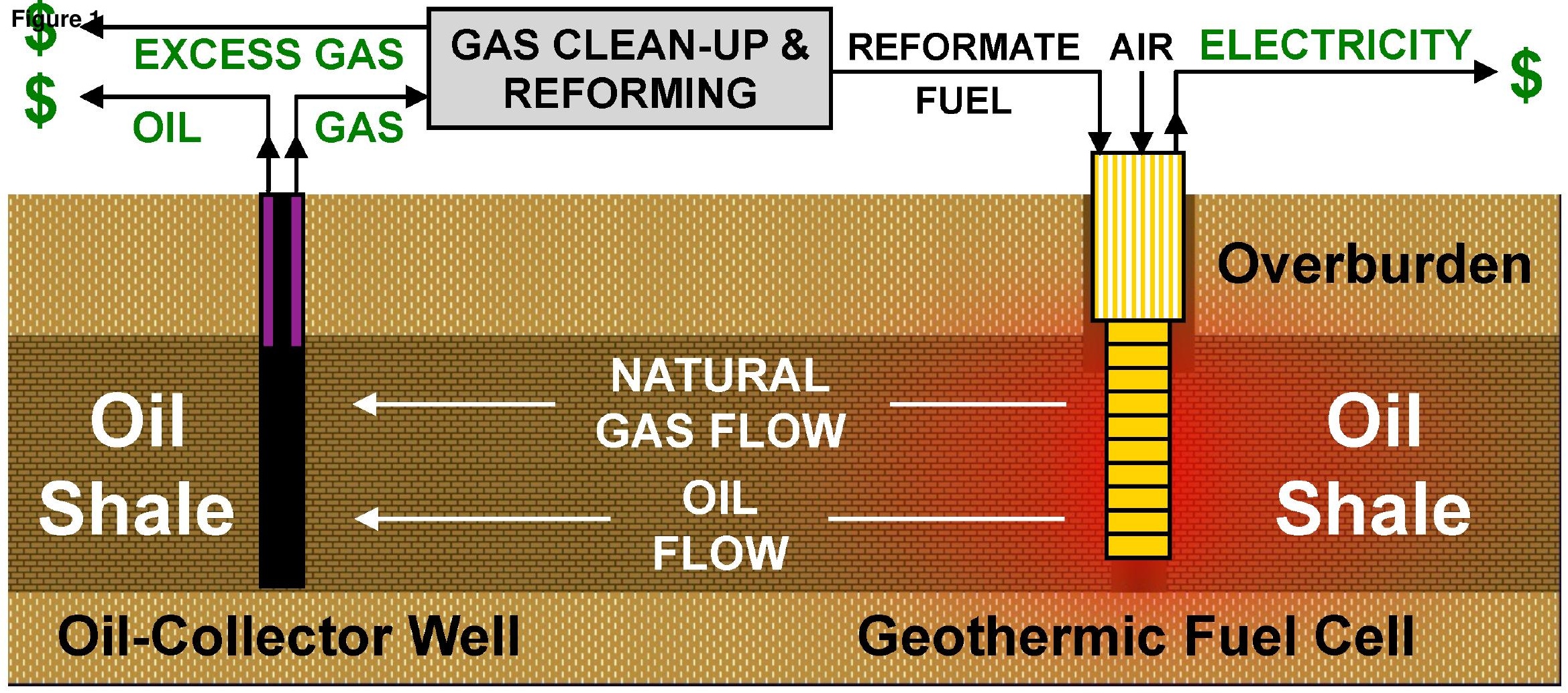


Figure 2
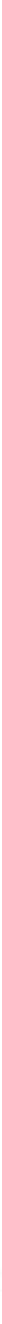


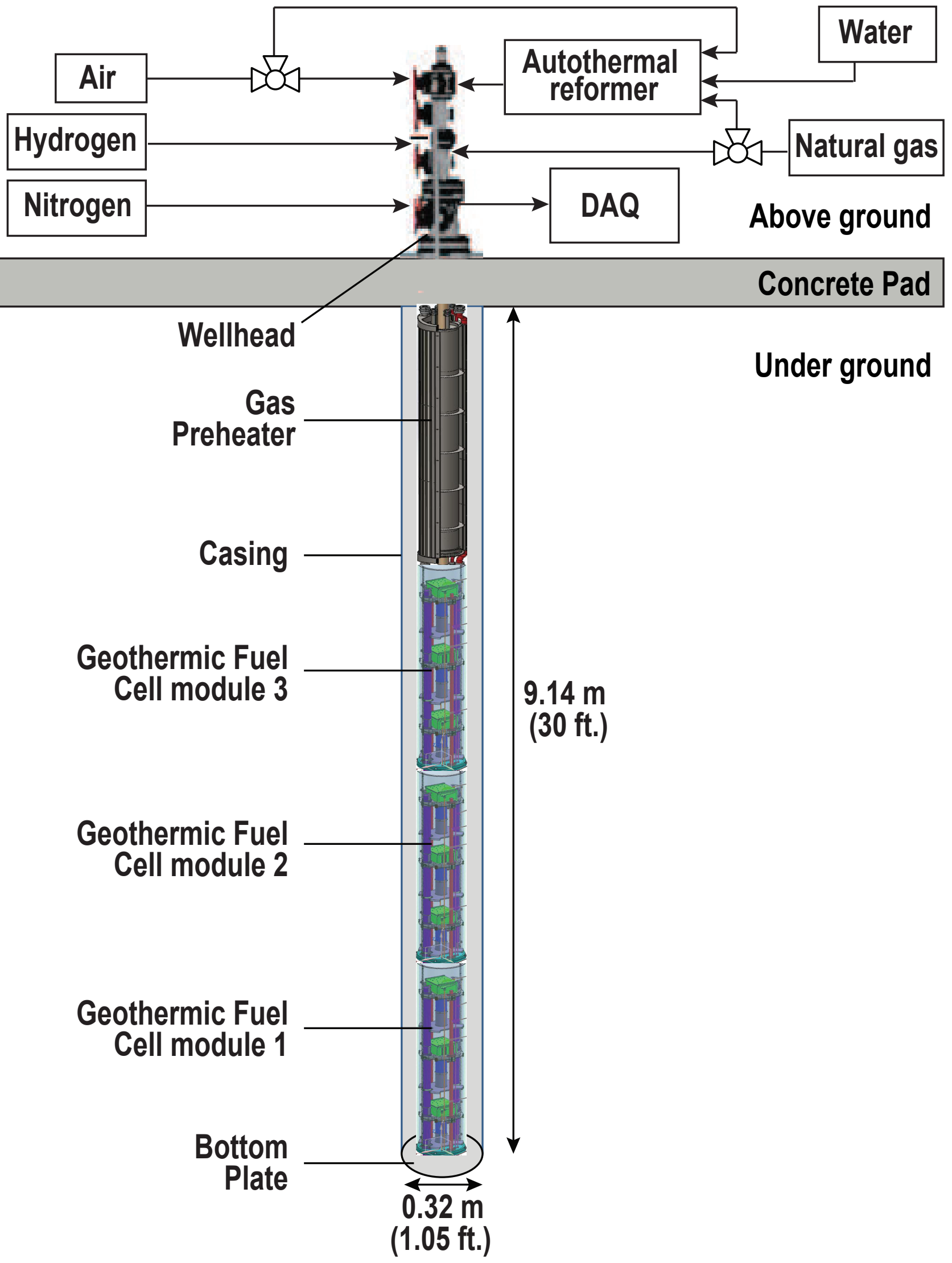




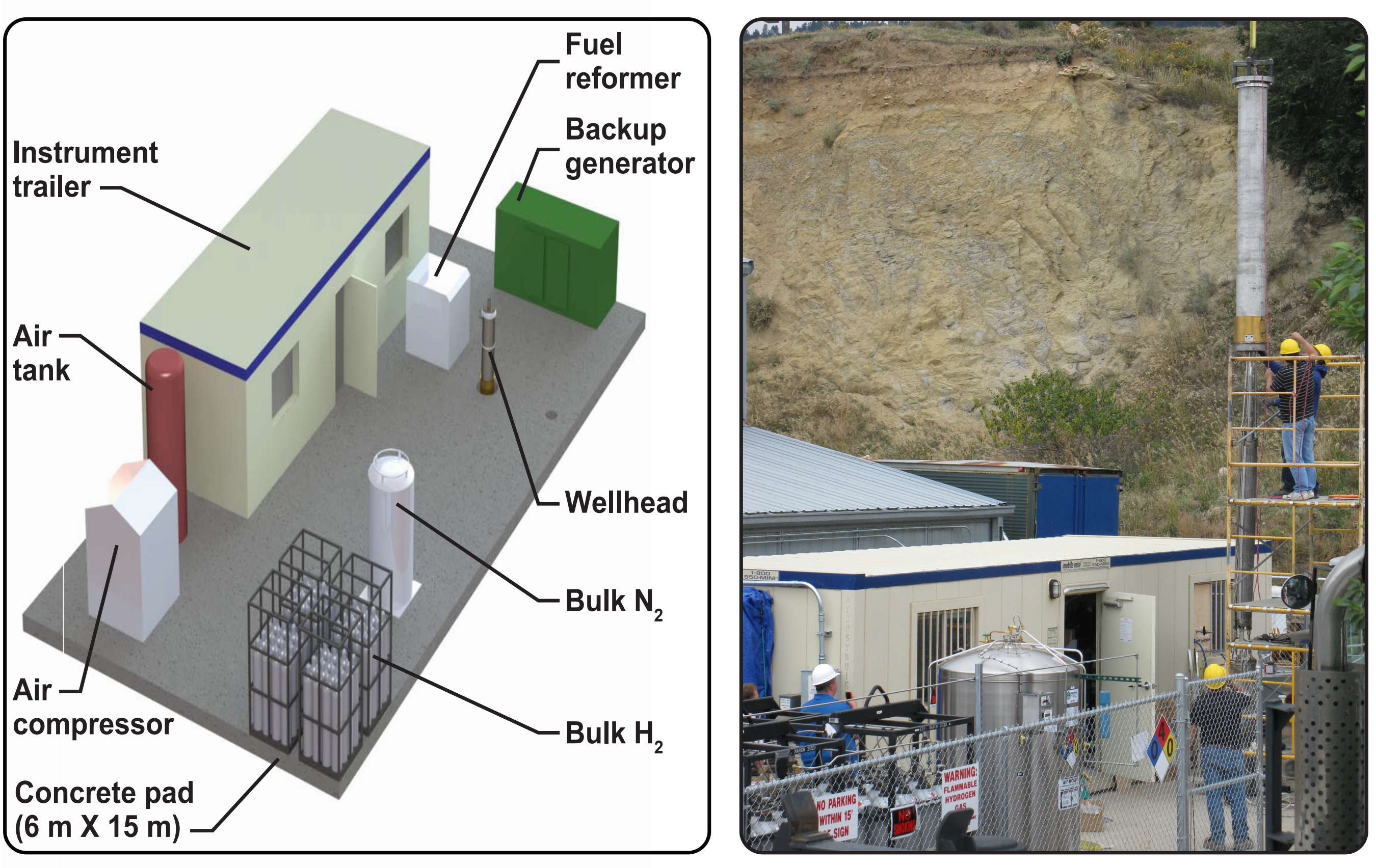




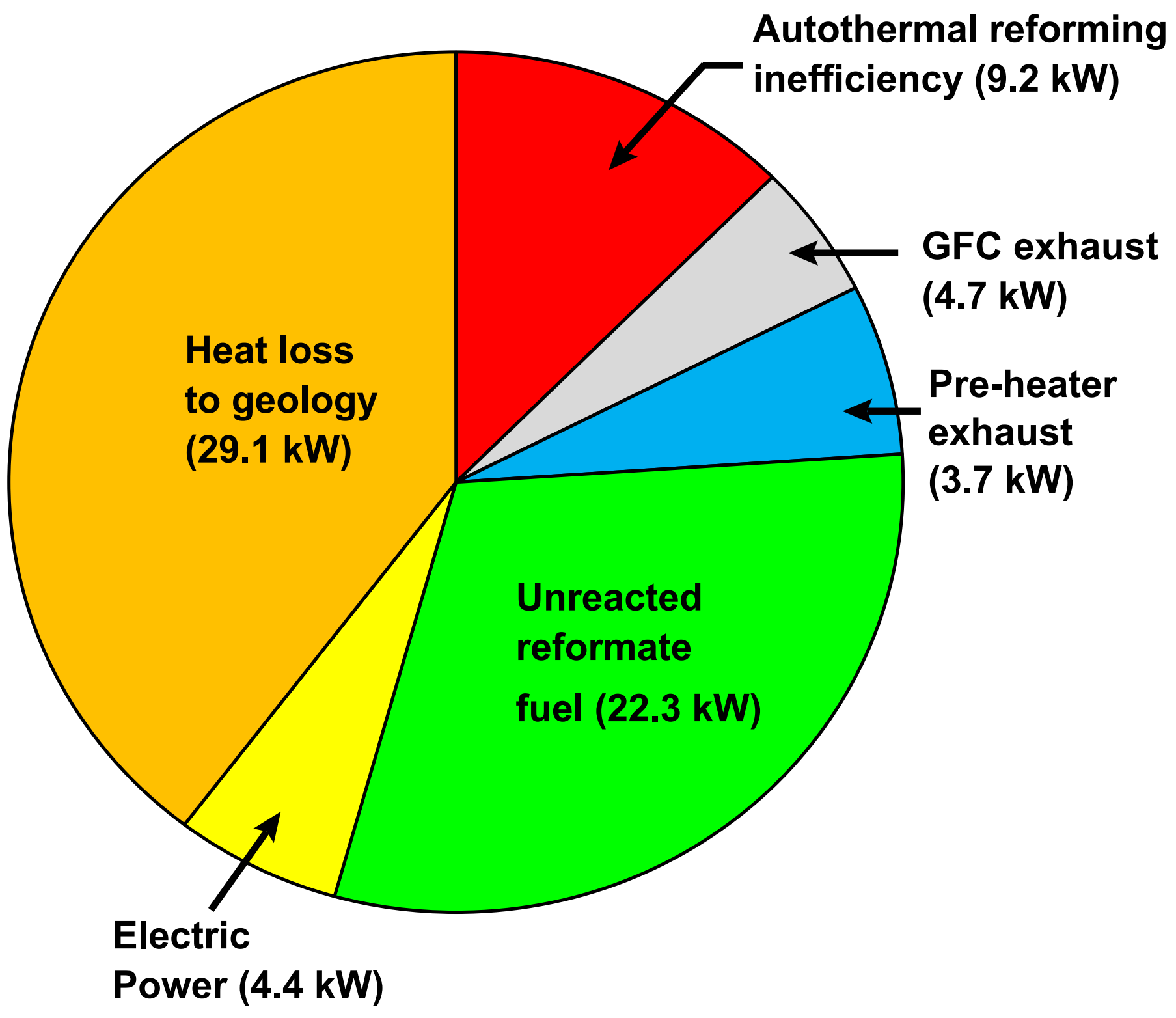




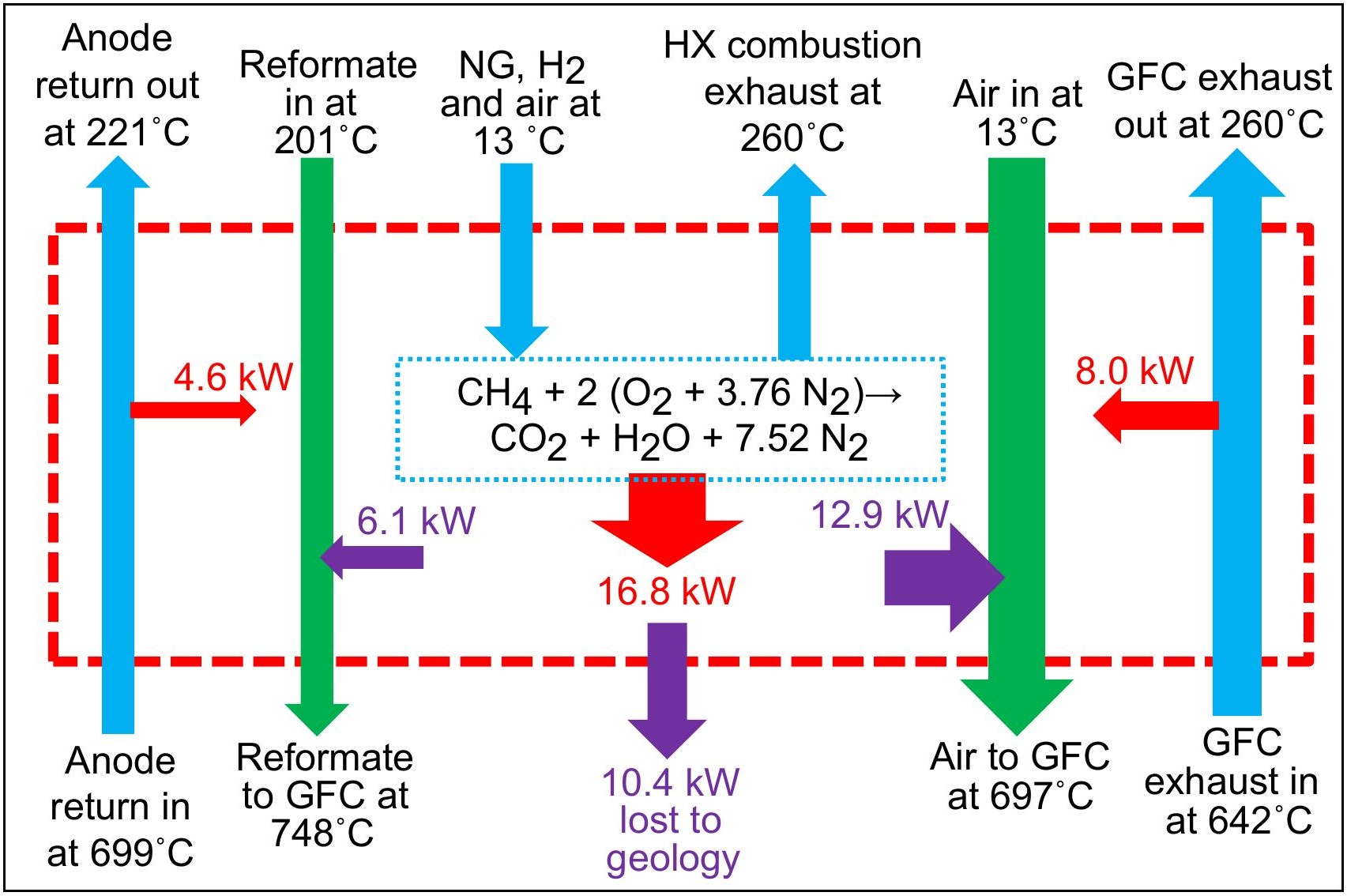



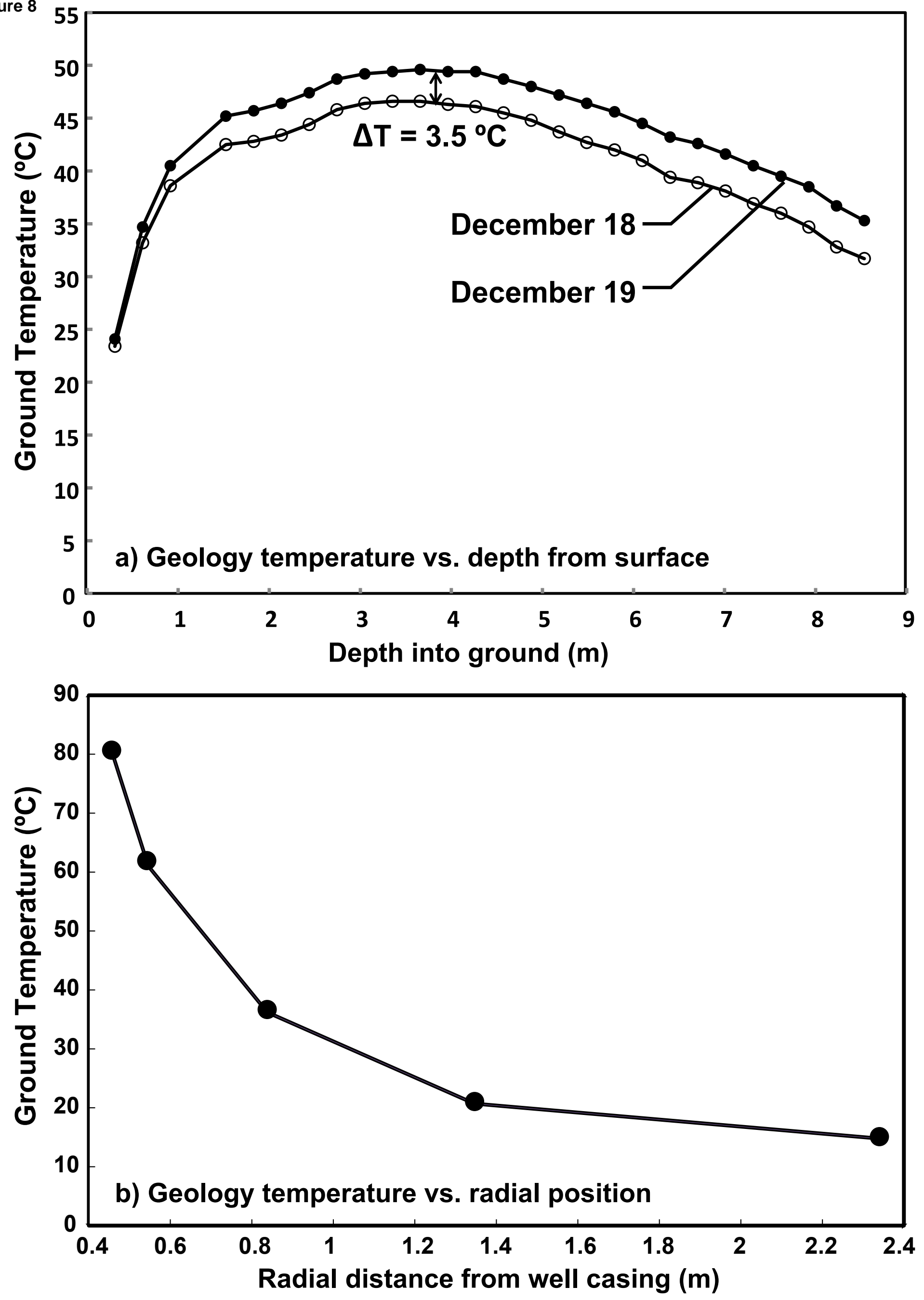


\section{LIST OF FIGURES}

Figure 1: Illustration of the Geothermic Fuel Cell concept, solid-oxide fuel cells provide the thermal energy to heat the oil shale formation.

Figure 2: $\quad$ Schematic of a single Geothermic Fuel Cell module. Three such modules were joined and placed within the earth as part of this demonstration.

Figure 3: $\quad$ Geothermic Fuel Cell system architecture.

Figure 4: $\quad$ Layout of in-ground Geothermic Fuel Cell outdoor test site (left); photograph taken during GFC installation (right).

Figure 5: $\quad$ Saridea preheater/heat-exchanger assembly.

Figure 6: Distribution of energy across the Geothermic Fuel Cell system at the 65-A operating point.

Figure 7: Illustration of the heat and gas flows through the preheat assembly. The dashed red line represents the physical boundaries of the preheater. Line thicknesses reflect the magnitude of the heat and gas flows into and out of the preheater.

Figure 8: Geology temperature: a) as a function of vertical depth from the surface measured on consecutive days of testing; b) as a function of radial distance from the sidewall of the casing in which the Geothermic Fuel Cell assembly is placed. Measurements were taken at a vertical position of $4 \mathrm{~m}(13 \mathrm{ft}$.) below the surface.

\section{LIST OF TABLES}

Table 1: $\quad$ Performance of the in-ground Geothermic Fuel Cell system at the 65-A operating condition. 